\title{
Determination of Characteristic Points and Counterfeiting'S Market Segmentation in Main Factorial Plan
}

\author{
Moyo Nzololo ${ }^{1}$ \\ ${ }^{1}$ Doctor - Assistant At The Faculty Of Economic Science, Université Marien Ngouabi, Esgae Congo Brazzaville. \\ Phone: +242066548613 \\ Correspondence: Moyo Nzololo, Doctor - Assistant At The Faculty Of Economic Science, Université Marien Ngouabi, \\ Esgae Congo Brazzaville.
}

Received: March 24, 2016

Accepted:March 29, 2016

Available online: April 14, 2016

doi:10.11114/aef.v3i3.1551

URL: http://dx.doi.org/10.11114/aef.v3i3.1551

\begin{abstract}
This paper suggests an economic analysis based upon the determination of characteristic points and a market segmentation of counterfeiting from the curves of the demand of non- deceptive counterfeiting and the supply of deceptive counterfeiting, represented simultaneously in the main factorial plan, coming from main components analysis with varimax rotation.
\end{abstract}

Keywords: market, market segmentation, counterfeiting, demand, non-deceptive counterfeiting, supply, deceptive counterfeiting, main factorial plan, main components analysis.

\section{Introduction}

In the context of non-deceptive counterfeiting, the probit model has made it possible to identify strategic variables of counterfeit products: attractive price for counterfeit CDs, scarcity of genuine products, knowledge of points of sale of counterfeit products, attitude while buying a counterfeit product, and contract of guarantee on a counterfeit product (Moyo Nzololo \& Makany, 2015). From the main components analysis (ACP) with varimax rotation, the supply of deceptive counterfeiting has enabled the identification of two factors in the main plan: the attractive price of counterfeit products and the scarcity of genuine products (Moyo Nzololo, 2016). What comes out is the fact that both factors generalize the first two strategic variables supplied by the probit model, that is, the attractive price for counterfeit CDs and the scarcity of genuine CDs.

The objective of this paper is to represent, in the same plan, the supply and demand of counterfeit products in one hand, and draw an inference from such supply and demand in another hand.

Our core issue focuses on two research questions:

- Why can two curves originated respectively from non-deceptive counterfeiting and deceptive counterfeiting be represented in the same plan?

- What are the representation axes that can be considered for both curves?

We have set forth two hypotheses:

$\mathrm{H} 1$ : the consumer is either accomplice or victim of counterfeiting. He is at the center of counterfeiting.

H2: the main plan supplied by the varimax rotation ACP (main components analysis) makes it possible to represent two curves.

\section{Theoretical framework}

In today's competitive business environment, there are many companies that supply counterfeit products to the markets in order to increase their profitability by using the brands of other companies (Riasi, 2015; Riasi \& Amiri Aghdaie, 2013). These counterfeit products are sold without the authorization of the original brand owners and negatively affect the consumer welfare (Ansari \& Riasi, 2016).

In the context of non-deceptive counterfeiting, the consumer knows that he is buying counterfeit products (Bloch et al., 1993; Grossman \& Shapiro, 1988a,b ; Maître et Perrino, 2007). As he is aware of that, the consumer is therefore 
accomplice of counterfeiting. Counterfeit products are generally of poor quality; and owing to the price, materials used and place of purchase (Bamossy and Scammon, 1985: Chakraborthy et al., 1997; Gentry et al., 2006), it is possible for the consumer to make a distinction between genuine products and bogus ones.

In the context of deceptive counterfeiting, the consumer thinks that he is buying a genuine product, while it is actually a counterfeit one (Grossman \& Shapiro, 1988a; Bloch et al., 1993; Le Roux et al., 2006; Danand, 2009). Given that he does not know this, the consumer is therefore a victim of counterfeiting. He is a victim of counterfeiters (manufacturers, sellers) as he has imperfect information on the quality of the products that may be bogus-bogus, bogus-genuine, or genuine-bogus. As Roudaut (2011) explains it, "the fully counterfeit product is entirely bogus (rough or approximate copy), the bogus-genuine is a bogus manufactured with the genuine, and the genuine-bogus might be confused with the genuine but it is a bogus («authentic » copy)"

The counterfeiting market has therefore two determinants, the supply $(\mathrm{O})$ and the demand $(\mathrm{D})$, which can be represented in a plan.

Numerous studies on counterfeiting markets have laid an emphasis on samples of students because they are vulnerable targets for counterfeiters, notably because of their limited purchasing power or budget (Krémer et al., 2008; Müller et al., 2011; Moyo Nzololo, 2014).

\section{Material and Method}

The material is made up of results obtained from economic analyses that we have conducted on non-deceptive and deceptive counterfeiting in Congo Brazzaville (Moyo Nzololo \& Makany, 2015: Moyo Nzololo, 2016). The method used is that of graphic analysis

\subsection{Material}

In the context of deceptive counterfeiting, the varimax rotation ACP applied to 1123 students from the Brazzaville «Ecole Supérieure de Gestion et d'Administration des Entreprises » (ESGAE, a College of Business Administration) in Congo according to 141 items, made it possible to identify, in the main plan, two decisive factors on the counterfeiting market: the attractive price for counterfeit products and the scarcity of genuine products. It is therefore in such a main plan that we are going to conduct our graphic analysis.

\subsection{Method}

The method considered is the graphic one. As Zelazny (1989) highlights it, "A graphic does not clothe any ultimate goal in itself; it is a visual help. What really matters is what you mean or demonstrate: the message you would like to convey".

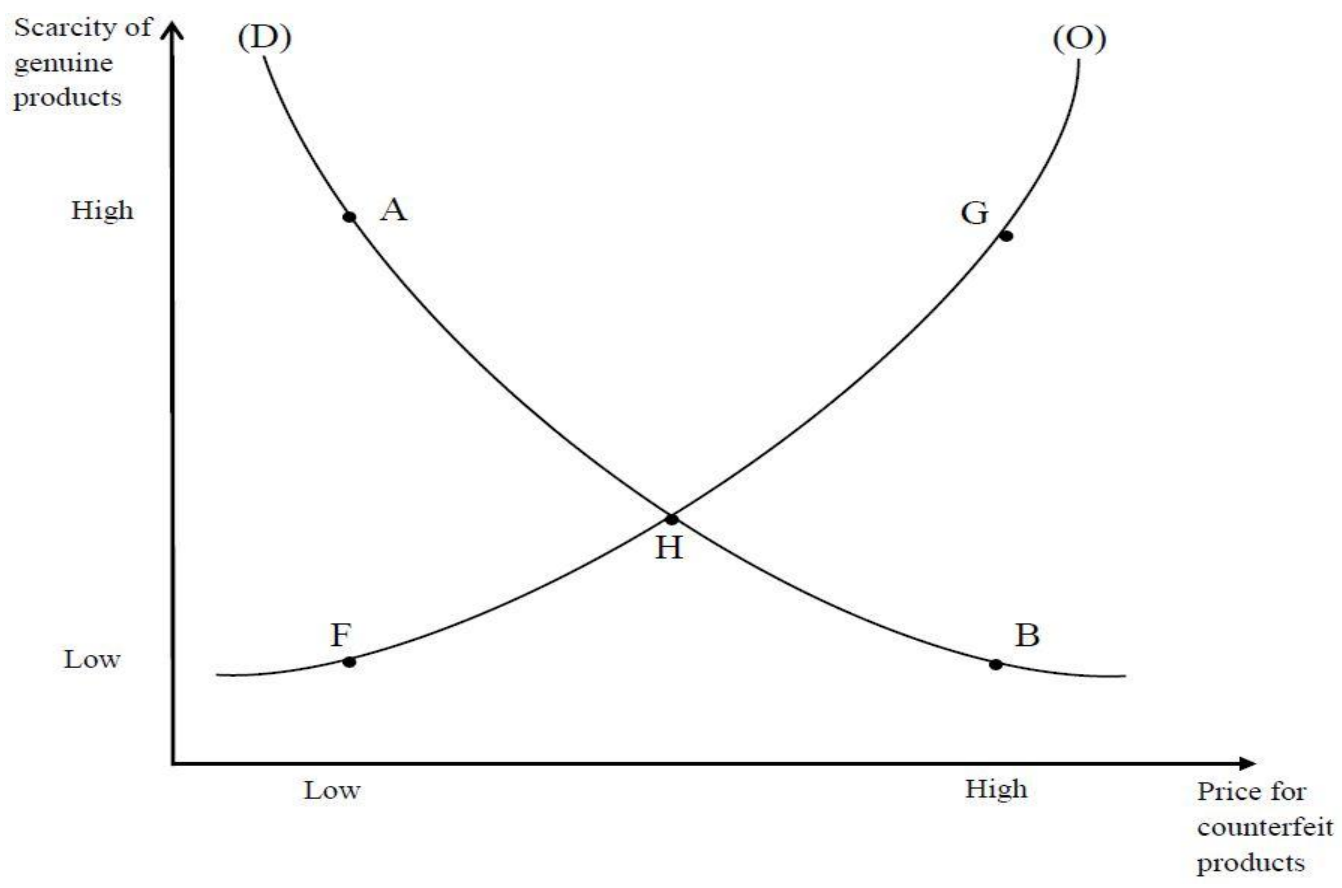

Figure 1. Curves of the supply (O) and the demand (D) on the counterfeiting market

The analysis has made it possible for us to identify five characteristic points: 
- $\quad$ On the curve (D) : points A and B

- $\quad$ On the curve $(\mathrm{O})$ : points $\mathrm{F}$ and $\mathrm{G}$

- $\quad$ Point $\mathrm{H}$ located at the intersection of curves (D) and (O)

\section{Results and Discussion}

In this chapter, we present five characteristic points of the counterfeiting market and a segmentation of such a market linked to four of those points.

\subsection{Characteristic Points of the Counterfeiting Market}

\section{a. On Curve (D)}

\section{Point A}

This point corresponds to the situation when the price of the counterfeit product is low, therefore attractive, while the scarcity of genuine products is high. There are few genuine products. Given that the price of the counterfeit product is inferior to the price of the original product, the demand for the counterfeit product is high. Point A expresses the situation when the points of sale of counterfeit products are known by consumers, and there is no obstacle to reach such points of sale. Point $\mathrm{A}$ is a place where price reduction is rather common.

\section{Point B}

This point corresponds to the situation when the price of the counterfeit product is high and the scarcity of genuine products is weak. There are plenty of genuine products. Given that the price of the counterfeit product is high, but inferior to the price of the genuine product, the consumer will seek to buy the genuine product. Genuine products are called Giffen goods. Point B is also the place where the consumer uses the bargaining technique in order to acquire the genuine product instead of the counterfeit one which is nevertheless cheaper than the counterfeit product. That is notably the case for electrical household appliances in Congo Brazzaville where sellers do not hesitate to present both the counterfeit product and the genuine one, with a price difference or margin which is not always considerable (Moyo Nzololo, 2014). Point B is the place where counterfeit products have little chance to survive.

\section{b. On Curve (O)}

Point F

This point corresponds to the situation when the price of the counterfeit product is low, therefore attractive, and the scarcity of genuine products is weak. Consequently, there are plenty of genuine products. As we are on the curve of deceptive supply, amongst the genuine products, there are bogus-bogus, bogus-genuine, and genuine-bogus counterfeit products. Danand (2009) describes mechanisms that make the consumer believe that he is buying a genuine product which is actually a counterfeit one. "apposing a pastille so as to mask the brand, obliterating the maker's mark, removing the label or packaging of origin for another different packaging, maintaining the maker's mark on a product that has been subject to reparation or transformation; delivering a product or service other than the one expected, is substitution of the genuine product for another one without the knowledge of the consumer". Point $\mathrm{F}$ is a place for mass distribution of numerous and various counterfeit products.

Point G

This point corresponds to the situation when the price of the counterfeit product is high and the scarcity of genuine products is high. Consequently, there are few genuine products. Point $\mathrm{G}$ expresses the Gresham law according to which "Bad currency chases away good currency": counterfeit products hunt genuine products down. In a situation of imperfect information circulation, poor quality products take precedence over genuine ones (Akerlof, 1970). Ever since, Counterfeit products price match that of genuine products, and such price is therefore high. Point $G$ is a place of excessive tariffication. Point $G$ is also the place for the counterfeiting of luxury products. As for luxury products counterfeiting, those products correspond to by-products whose resemblance with key attributes of genuine products is more or less remarkable: second-hand, surplus, legitimate imitation, good-quality counterfeiting and poor-quality (Gentry et al., 2006).

\section{c. The point of $(\mathrm{D})$ and $(\mathrm{O})$ intersection}

\section{Point $\mathrm{H}$}

It is a point of sale where counterfeiters try to deceive the consumers who, in their turn, think that they are buying genuine products, while those products are actually counterfeit ones. We are mainly in the context of genuine-bogus and bogus-genuine counterfeit products. Point $\mathrm{H}$ corresponds to supermarkets, neighboring stores in which one can find, on shelves, genuine products, along with counterfeit products that have been inserted into official distribution circuits. Points $\mathrm{H}$ are also gray markets. There are plenty of counterfeit goods in gray markets. According to Higgins and Rubin 
(1986), there are gray markets when products are, in one hand, imported in a country - within which the cost of living is high - by people who have received no authorization from the manufacturer to engage the responsibility of the latter for such an import and, in another hand, to sell products at different price in different countries. Such gray markets that are also found in Congo sell, among others, electrical home appliances (Moyo Nzololo \& Makany, 2009a). Branded goods are sold there, with no credible information whether the product has been imported by a distributor who has a license, which insures protection and guaranty as far as quality is concerned. Guaranty is either partial or short-living, but non-existent most of the time. Gray markets products may correspond to brands' leftovers. Yet, it is also possible to reckon, or assume that gray markets are an outlet for "genuine-bogus" products whose authentication cannot clearly be determined, that is, subject to doubt.

\subsection{Market segmentation of counterfeiting}

In the global context of the struggle against counterfeiting, when genuine products are scarce, this thus means that there are few genuine products in the counterfeiting market. Consequently, the quality of counterfeit products supply is high, notably with the presence of genuine-bogus products; and the value of counterfeit products is high. On the other hand, when the scarcity of genuine products is weak or unimportant, this therefore means that there are plenty of genuine products on the market. Consequently, the quality of counterfeit products supply is weak, notably with the presence of bogus-bogus and bogus-genuine products. The value of counterfeit products is weak or unimportant. Table 1 below shows the four counterfeiting segments, described by the four points G, A, B and F.

Table 1. Segmentation of the counterfeiting market

\begin{tabular}{|c|c|c|}
\hline Price of the & High & \\
Quality of the \\
counterfeit product \\
supply product
\end{tabular}

If we consider the Dussart typology (1995), we notice that:

- G tallies with the «Overtariffication » segment,

- A tallies with the «Price Reduction » segment,

- $\quad$ B tallies with the «Suicide » segment,

- $\quad F$ tallies with the «Mass Distribution » segment.

\section{Conclusion}

In this paper, we have shown that on the counterfeiting market, both curves (D) and (O) coming respectively from non-deceptive counterfeiting and deceptive counterfeiting can be represented within the same plan, because if we side by the demand, the consumer is accomplice (non deceptive counterfeiting). But if we side by the supply, the consumer is a victim (deceptive counterfeiting). The review of both curves in the main plan provided by the varimax rotation ACP has shown that the attractive price of the counterfeit product and the scarcity of genuine products are among the factors that water the life of the counterfeiting market, in light with the five characteristic points, the market segmentation and the counterfeiting obtained.

\section{Acknowledgements}

I would like to express my deepest thanks to Professor Roger Armand Makany for scientific guidance and Mister Jean Victor Biyekele for the translation of this paper English version. 


\section{References}

Akerlof, G. A. (1970). The market for "Lemons": Quality Uncertainty and the Market Mechanism, Quarterly Journal of Economics, 84(3), 488-500

Ansari, A., \& Riasi, A.(2016). An Investigation of Factors Affecting Brand Advertising Success and Effectiveness. International Business Research, 9(4), 20-30,http://dx.doi.org/ibr.v9n4p20

Bamossy, G., \& Scammon, D. (1985). Product counterfeiting and manufacturing beware. In Hirshmen, E.C. and M.B. Holbrook, (coord.), 12, Provo, UT, Association for consumer Research

Bloch, P. H., Bush, R. F., \& Campbell, L. (1993). Consumer « accomplices » in product counterfeiting. Journal of Consumer Marketing, 10(4), 27-36.

Chakraborthy, G., Alfred, A., Sukhdial, A. S., \& Bristol, T. (1997). Use of negative cues to reduce demand for counterfeit products. In Brucks, M., and MacInnis, D. J. (coord.), 24, Provo, UT, Association for Consumer Research

Danand, C. (2009). Contrefaçon de marque : de quoi parle-t-on ? Comment s'en protéger ?, Décisions Marketing, 53, 53-61.

Dussart, C. (1995). Questions de prix, Décisions Marketing, 6, 23-32.

Gentry, J. W., Putrevu, S., \& Schultz, C. (2006). The effects of counterfeiting on consumer search. Journal of Consumer Behavior, 5(3), 245-256.

Grossman, G. M., \& Shapiro, C. (1988 a). Foreign counterfeiting of status goods, Quarterly Journal of Economics, 103(1), 79-100.

Grossman, G. M., \& Shapiro, C. (1988b). Counterfeit-product trade, The American Economic Review, 59-75

Higgins, R. S., \& Rubin, P. H. (1986). Counterfeit goods. Journal of Law \& Economics, 29(2), 211-230.

Krémer, F., Viot, C., Le Roux, A., \& Poncin, I. (2008). Les consommateurs face à la contrefaçon : une comparaison entre Belges et Français, Reflets et perspectives de la vie économique, XLVII(2), 61-70.

Le Roux, A., Viot, C., \& Krémer, F. (2006). Les déterminants de l'achat de produits de contrefaçon : le consommateur face à l'attaque des clones, Actes du 22e Congrès de l'Association Française de Marketing, Nantes, 1-29

Maitre P., \& Perrino, M. (2007). Contrefaçon et ostentation, Revue d'Economie Industrielle, 117, 75-92

Moyo, N. (2014). Contribution à l'analyse de la contrefaçon : Cas du Congo Brazzaville, Thèse de doctorat en sciences économiques, Université de Caen Basse-Normandie (France)

Moyo, N. (2016). Economic analysis of deceptive counterfeiting in Congo Brazzaville, IJRME,

Moyo, N., \& Makany, R. A. (2009a). Analysis of counterfeit in Congo-Brazzaville: the case of TV sets (Part I), Review of Management and Economic Engineering, 8(2), 217 -225

Moyo, N., \& Makany, R. A. (2015). Economic analysis of non-deceptive counterfeiting in Congo Brazzaville, Int.J.Eco.Res. IJER, 6(6), 8-21

Müller, B., Kocher B., \& Ivens, B. (2011). Contrefaçons de produits de luxe, Revue française de gestion, 212, 45-61

Riasi, A. (2015). Competitive Advantages of Shadow Banking Industry: An Analysis Using Porter Diamond Model. Business Management and Strategy, 6(2), 15-27. http://dx.doi.org/10.5296/bms.v6i2.8334

Riasi, A., \& Amiri Aghdaie, S. F. (2013). Effects of a Hypothetical Iranian Accession to the World Trade Organization on Iran's Flower Industry. Consilience: The Journal of Sustainable Development, 10(1), 99-110.http://dx.doi.org/10.7916/D8HQ3ZK8

Roudaut, M. R. (2011). La contrefaçon : un crime invisible, Cahiers de la sécurité, 15, 25

Zelazny, G. (1989), Dites-le avec des graphiques, InterEditions, Paris.

\section{$(\mathrm{cc}) \mathrm{BY}$}

This work is licensed under a Creative Commons Attribution 3.0 License. 